\title{
Patterns of partial RNA editing in mitochondrial genes of Beta vulgaris
}

\author{
Jeffrey P. Mower • Jeffrey D. Palmer
}

Published online: 14 November 2006

(C) Springer-Verlag 2006

\section{Erratum to: Mol Genet Genomics DOI 10.1007/s00438-006-0139-3}

Unfortunately, the address was published with errors.

The complete is given here:

J. P. Mower $(\bowtie)$ · J. D. Palmer

Department of Biology, Indiana University,

Bloomington, IN 47405, USA

e-mail: jpmower@indiana.edu

Present Address:

J. P. Mower

Smurfit Institute of Genetics,

Trinity College Dublin,

Dublin 2, Ireland

Phone: +353-1-8962319

e-mail: mowerj@tcd.ie

The online version of the original article can be found at http://dx.doi.org/10.1007/s00438-006-0139-3.

J. P. Mower $(\bowtie) \cdot$ J. D. Palmer

Department of Biology, Indiana University,

Bloomington, IN 47405, USA

e-mail: jpmower@indiana.edu

J. D. Palmer

e-mail: jpalmer@bio.indiana.edu

Present Address:

J. P. Mower

Smurfit Institute of Genetics, Trinity College Dublin,

Dublin 2, Ireland

e-mail: mowerj@tcd.ie 